\title{
The magnetism of mantle xenoliths and potential implications for sub-Moho magnetic sources
}

\author{
Eric C. Ferré, ${ }^{1}$ Sarah A. Friedman, ${ }^{1}$ Fatíma Martín-Hernández, ${ }^{2,3}$ Joshua M. Feinberg, ${ }^{4}$ \\ James A. Conder, ${ }^{1}$ and Dmitri A. Ionov ${ }^{5}$ \\ Received 3 October 2012; revised 15 December 2012; accepted 19 December 2012; published 16 January 2013.
}

[1] Mantle xenoliths provide our clearest look at the magnetic mineral assemblages below the Earth's crust. Previous investigations of mantle xenoliths suggested the absence of magnetite and metals, and proposed that even if such minerals were present, they would be above their Curie temperatures at mantle conditions. Here we use magnetic measurements to examine four exceptionally fresh suites of xenoliths, and show that magnetite occurs systematically, albeit in variable amounts depending on the tectonic setting. Specimens from low geotherm regions hold the largest magnetic remanence. Petrographic evidence shows that this magnetite did not form through serpentinization or other alteration processes. Magnetite, which is generally stable at the P-T- $\mathrm{fO}_{2}$ conditions in the uppermost mantle, had to have formed either in the mantle or, less likely, in the volcanic conduit. In some cases, the source of the xenoliths was at temperatures $<600^{\circ} \mathrm{C}$, which may have allowed this portion of the lithospheric mantle to carry a magnetic remanence. Whether such magnetite carries a remanent magnetization or is simply the source of a strong induced magnetization, these new results suggest that the concept of the Moho as a major magnetic boundary needs to be revisited. Citation: Ferré, E. C., S. A. Friedman, F. Martín-Hernández, J. M. Feinberg, J. A. Conder, and D. A. Ionov (2013), The magnetism of mantle xenoliths and potential implications for sub-Moho magnetic sources, Geophys. Res. Lett., 40, 105-110, doi:10.1029/2012GL054100.

\section{Introduction}

[2] Previous investigators viewed the Moho as a fundamental boundary separating the magnetized crust from the non-magnetic mantle [Wasilewski et al., 1979; Wasilewski and Mayhew, 1992]. This model, central to the interpretation of aeromagnetic and satellite data, argues that the mantle does not contain ferromagnetic phases capable of carrying

All Supporting Information may be found in the online version of this article. USA.

${ }^{1}$ Department of Geology, Southern Illinois University, Carbondale, IL,

${ }^{2}$ Department of Geophysics Universidad Complutense de Madrid, Madrid, Spain.

${ }^{3}$ Instituto de Geociencias IGEO (UCM-CSIC), Fac. CC. Físicas, Madrid, Spain.

${ }^{4}$ Institute for Rock Magnetism, University of Minnesota, Minneapolis, MN, USA.

${ }^{5}$ Université J. Monnet \& UMR6524-CNRS, 42023, Saint-Etienne, France.

Corresponding author: E. C. Ferré, Department of Geology, Southern Illinois University, Carbondale, IL 62901, USA. (eferre@geo.siu.edu)

(C)2012. American Geophysical Union. All Rights Reserved. 0094-8276/13/2012GL054100 a magnetic remanence. Even if present, such minerals would be above their respective Curie temperatures $\left(\mathrm{T}_{\mathrm{c}}\right)$ and they would contribute negligibly to long wavelength magnetic anomalies (LWMA). Numerous studies applied this model widely across all tectonic settings [e.g., Maus et al., 2007].

[3] Recent observations suggest that this model ought to be revisited. First, studies on the spectral structure of aeromagnetic anomalies suggest that the forearc mantle may carry a significant remanence [Cascadia: Bostock et al., 2002; Blakely et al., 2005]. Other reports of magnetization in the upper mantle include the Ligurian Sea [Chiozzi et al., 2005], the Caribbean Sea [Counil et al., 1989] and other oceanic basins [Arkani-Hamed and Strangway, 1987]. The non-magnetic mantle model neglects the fact that portions of the lithospheric mantle cool below the Curie temperature of magnetite, including tectonic settings with depressed geotherms (subduction zones, cratons, and old oceanic lithosphere). Second, determinations of $f_{2}$ in the upper mantle support the stability of magnetite above the wüstite-magnetite buffer [Frost and McCammon, 2008; Goncharov et al., 2012]. Third, many xenoliths used in earlier studies [Wasilewski et al., 1979; Wasilewski and Mayhew, 1992] were contaminated by their host basaltic melt, altered by supergene fluids, or were atypical of bulk mantle composition. The forthcoming launch of the Swarm satellite constellation may contribute to a better understanding of the role of deep magnetic sources [Friis-Christensen et al., 2006] although it is uncertain that relatively small anomalies, such as that in Cascadia, will be resolved at satellite altitude.

[4] Mantle xenoliths provide our clearest view of lithospheric mantle conditions because they ascend through the lithosphere within a few hours [Demouchy et al., 2006], thereby minimizing the opportunity for the formation of secondary magnetic minerals through alteration. Magnetite may form in olivine and pyroxenes through exsolution at mantle conditions [Sen and Jones, 1988], or by crack healing and metasomatism during xenolith ascent [Drury and van Roermund, 1988]. Despite their rapid ascent, xenoliths may be contaminated by the host magma along cracks and mineral grain boundaries. Similarly, hematite can grow along grain boundaries during supergene alteration. Notwithstanding these processes, unaltered mantle xenoliths still provide the best available record of upper mantle magnetic mineralogy, and we have taken every precaution to avoid altered xenoliths in this study.

\section{Petrography of four series of fresh mantle xenoliths}

[5] Previous petrological and mineralogical studies constrain the eruption age, the pressure, temperature and redox equilibration conditions for each of the four xenolith suites: 


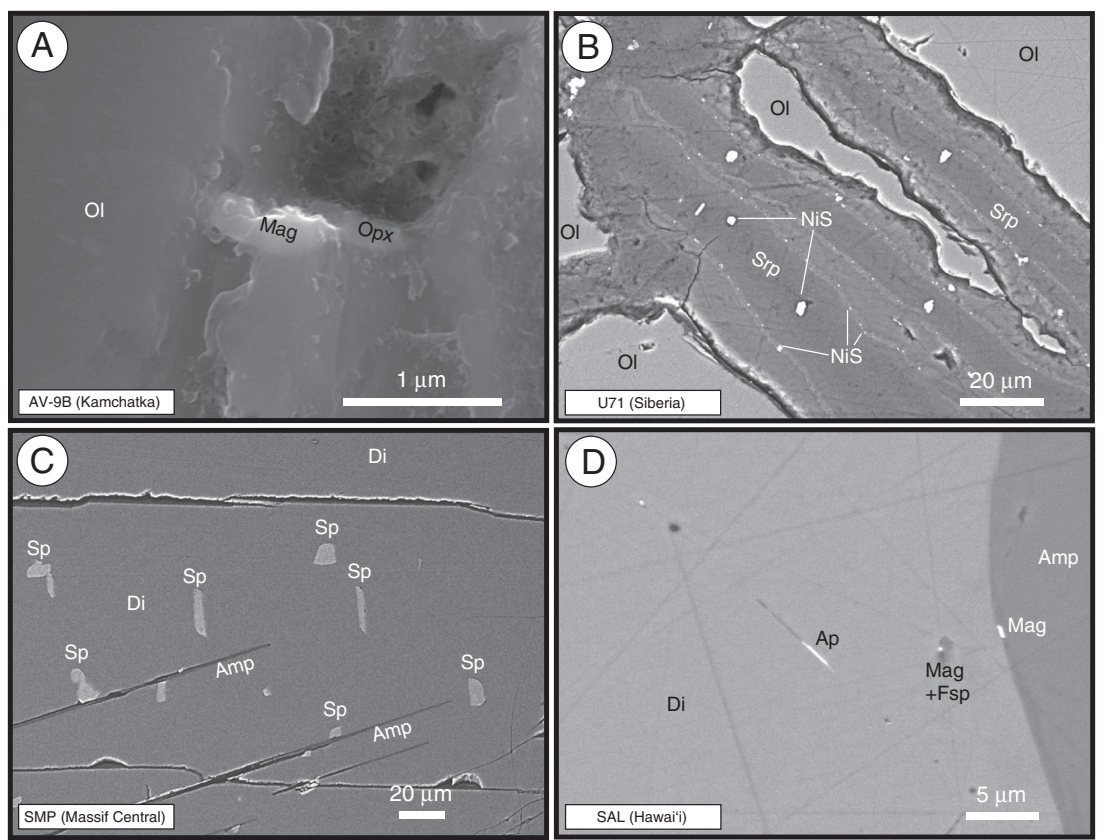

Figure 1. Scanning electron microscope images of thin sections of peridotite xenoliths. (A) Secondary electron image of a harzburgite xenolith from Avacha volcano, Kamchatka arc. The rock is free of post-eruptive alteration along grain boundaries. Olivine (Ol) grains host $200 \mathrm{~nm}$ x $500 \mathrm{~nm}$, needle-shaped magnetite (Mag) inclusions adjacent to orthopyroxene (Opx) exsolution lamellae. (B) Backscattered electron (BSE) image of a garnet harzburgite xenolith from Udachnaya kimberlite, Siberian craton [LOI=0.04, Ionov et al., 2010]. A few Ol grain boundaries have 10-20 $\mu \mathrm{m}$-thick layered rinds of serpentine (Srp) including nickel sulfides (NiS). (C) BSE image of lherzolite xenolith from French Massif Central volcano. $\mathrm{Ol}$ and diopside (Di) grains display exsolved $\mathrm{Cr}$-rich spinels (Sp), adjacent to exsolved amphibole (Amp) lamellae. (D) BSE image of lherzolite xenolith from Salt Lake volcano, Hawai'i. Di grains host inclusions of feldspar (Fsp) and apatite (Ap). Exsolved Mag occur within Di and along Opx-Amp grain boundaries.

Kamchatka island arc [Ionov, 2010], Siberian craton [Ionov et al., 2010; Goncharov et al., 2012], French Massif Central continental plume [Lenoir et al., 2000], and Hawai'i oceanic hot spot [Sen, 1988].

[6] Within each xenolith suite, samples met the following criteria: i) xenoliths were larger than $80 \mathrm{~mm}$ in diameter, ii) $10 \mathrm{~mm}$ cubic specimens were extracted from near each xenolith's center which lacked any visible alteration, and iii) all xenoliths were free of inclusions and veins of host magmatic rocks. A third of the samples passed these tests. This protocol excludes xenoliths with obvious alteration and contamination, and yields macroscopically unaltered and uncontaminated xenoliths.

[7] Additional screening involves measuring loss-on-ignition (LOI), which is caused by loss of volatile components $(\mathrm{OH}, \mathrm{S}$, $\mathrm{CO}_{2}, \mathrm{Cl}$ ) during heating, and is broadly interpreted to reflect the degree of serpentinization. Only specimens with LOI < 1.00 weight $\%$ were included for further investigation, which eliminates excessively altered samples. In addition, the xenolith samples selected from the French Massif Central collection display an Alt-S\% $<10 \%$, indicating a low degree of alteration of their primary sulfides [Alard et al., 2011].

[8] The main silicate phases (olivine, orthopyroxene, clinopyroxene) exhibit limited chemical core-to-rim zonation [Sen, 1988; Lenoir et al., 2000; Ionov, 2010; Goncharov et al., 2012]. This absence of zonation attests to equilibration at high temperature and indicates that mineral assemblages observed in the studied xenoliths likely represent ambient mantle conditions. The short ascent duration typically reported for mantle xenoliths, as well as the large size of our samples, limits opportunities for xenolith re-equilibration with their host magmas [e.g., Demouchy et al., 2006; Peslier et al., 2008].

[9] In several specimens (e.g., iAv-9b, SAL), elongated grains of magnetite ( $\approx 0.5$ to $1 \mu \mathrm{m}$ ) occur within olivine and pyroxene in orientations parallel to distinct crystallographic planes within their silicate host (Fig. 1). This suggests that these magnetite grains formed either at mantle depths or during the xenolith ascent, but not through posteruption reaction with hydrous fluids.

\section{Magnetic properties of mantle xenoliths in different tectonic settings}

[10] Details on magnetic methods are given in the Appendix. Each xenolith sample yielded two 10-mm cubic specimens for magnetic analyses. Stepwise demagnetization of the natural remanent magnetization (NRM) was performed using alternating field up to $120 \mathrm{mT}$. The least altered specimens showed a single component of NRM and were kept for further tests. A few specimens' NRM demagnetization spectra displayed an additional high coercivity component, inferred to be carried by hematite, and were discarded because this mineral indicates that the specimen's original mineral assemblage was compromised by oxidation.

[11] All mantle xenoliths show a relatively narrow range of magnetic susceptibilities and a broad range of NRM values (Figure 2A; Supporting Information). The magnetic susceptibilities are consistent with a log normal distribution (Supporting Information). Low-field magnetic susceptibility $\left(K_{m}\right)$ is a proxy for the concentration and grain size of 

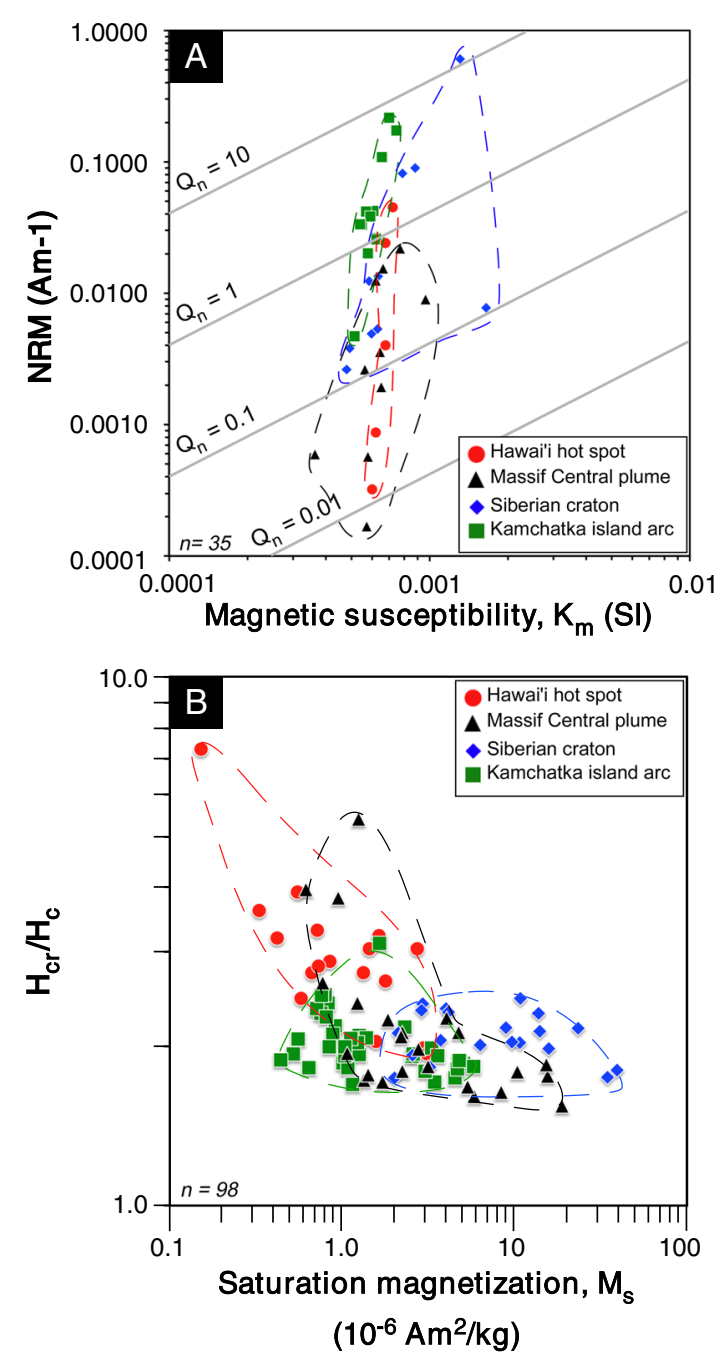

Figure 2. (A) Natural remanent magnetization vs lowfield magnetic susceptibility of peridotite xenoliths (see also Supporting Information). Koenigsberger ratio, $Q_{n}=\mathrm{NRM} /$ $\mathrm{K}_{\mathrm{m}} \mathrm{H}$ where $\mathrm{H}$ : local geomagnetic field intensity $=40 \mathrm{Am}^{-1}$. Each suite shows a relatively narrow range of $\mathrm{K}_{\mathrm{m}}$ and a broad range of NRMs. (B) $\mathrm{H}_{\mathrm{cr}} / \mathrm{H}_{\mathrm{c}}$ vs saturation magnetization (normalized to mass, in $10^{-6} \mathrm{Am}^{2} / \mathrm{kg}$ ). Specimens from low geotherm settings display lower average $\mathrm{H}_{\mathrm{cr}} / \mathrm{H}_{\mathrm{c}}$ ratios and lower $\mathrm{M}_{\mathrm{s}}$.

ferromagnetic minerals, and to a lesser degree, the concentration of paramagnetic minerals. The NRM intensity of mantle xenoliths varies broadly between $10^{-4}$ and $1 \mathrm{~A} / \mathrm{m}$, and is an expression of the abundance of single domain and pseudo-single domain sized grains in a specimen, as well as the strength of the Earth's magnetic field at the time of magnetization. The Koenigsberger ratio $\left(Q_{n}\right)$ represents the ratio of natural remanent magnetization to the induced magnetization in the Earth's field: $Q_{n}=\mathrm{NRM} / K_{m} \mathrm{H}$, where $K_{m}$ is the magnetic susceptibility in SI units and $\mathrm{H}$ is the local geomagnetic field intensity (here $40 \mathrm{~A} / \mathrm{m}$ ). Values higher than 1 indicate that the specimen's remanent magnetization will be the dominant contribution to magnetic anomalies, while values less than 1 indicate that the specimen's induced magnetization will be the primary contribution. Approximately one third of the xenoliths display $Q_{n}$ values $>1$, and if these specimens are representative of magnetic mineral assemblages in the lithospheric mantle, then these measurements suggest that the mantle's remanent magnetization may contribute to magnetic anomalies in low geotherm regions. Although there is a significant amount of overlap in the magnetic properties of xenoliths from different tectonic regions, on average, specimens from the Siberian craton and Kamchatka arc have higher NRM intensities than those from the Massif Central plume or the Hawai'i hot spot. Xenoliths from the Kamchatka subduction zone have the highest $Q_{n}$ values and their remanent magnetizations may play a more important role than their induced magnetizations in long wavelength magnetic anomalies. Importantly, the Kamchatka xenoliths are free of any post-eruption alteration [Ionov, 2010].

[12] The saturation magnetization normalized to mass $\left(\mathrm{M}_{\mathrm{s}}\right)$ constitutes a proxy for the concentration of ferromagnetic minerals in the xenoliths. The ratio of the coercivity of remanence $\left(\mathrm{H}_{\mathrm{cr}}\right)$ to the bulk coercivity $\left(\mathrm{H}_{\mathrm{c}}\right)$ is directly related to the median grain size of a specimen's ferromagnetic minerals. Although the values of magnetic hysteresis parameters significantly overlap between suites, they plot in different regions of the $\mathrm{M}_{\mathrm{s}} \mathrm{vs} \mathrm{H}_{\mathrm{cr}} / \mathrm{H}_{\mathrm{c}}$ diagram (Fig. 2B; Supporting Information). The magnetic properties of fresh mantle xenoliths vary with tectonic setting (Fig. 2; Table).

\section{Identification of the main ferromagnetic phases}

[13] All specimens produce major hysteresis loops that show the presence of at least one ferromagnetic phase. This ferromagnetic contribution varies between 1 and $70 \%$ of the bulk magnetic susceptibility with an average of $21 \%$ (Table 1; Supporting Information).

[14] Certain candidate minerals can be ruled out. Cr-rich spinel behaves ferromagnetically only within a specific compositional range [Schmidbauer, 1983], and in these mantle xenoliths the iron content of Cr-rich spinel is too low to carry a magnetic remanence. Iron-nickel sulfides, such as pentlandite, cannot contribute to remanence because they are paramagnetic at and above room temperature. The lack of a pyrrhotite transition around $30-34 \mathrm{~K}$ in low-temperature (LT)

Table 1. Magnetic properties of peridotite xenoliths in four distinct tectonic settings including (i) arithmetic mean magnetic susceptibility, (ii) average of the magnetic remanence vectors, (iii) Koenigsberger ratios calculated from the intensity of the resultant mean remanence vector and the mean magnetic susceptibility.

\begin{tabular}{|c|c|c|c|c|c|c|c|c|c|c|c|c|c|c|}
\hline \multirow[b]{2}{*}{ xenolith suite } & \multicolumn{5}{|c|}{ low-field susceptibility $\left(10^{-6}[\mathrm{SI}]\right)$} & \multicolumn{5}{|c|}{$\operatorname{NRM}\left(10^{-3}[\mathrm{~A} / \mathrm{m}]\right)$} & \multicolumn{4}{|c|}{ Qn } \\
\hline & $n$ & $\min$ & $\max$ & mean & stdv & $n$ & $\min$ & $\max$ & mean & stdv & $\min$ & $\max$ & mean & error \\
\hline Massif Central- continental plume & 24 & 362.67 & 964.33 & 621 & 125 & 10 & 4.72 & 217.00 & 6.2 & 7.5 & 0.01 & 0.72 & 0.3 & 0.3 \\
\hline Hawai's-oceanic hot spot & 17 & 511.13 & 723.37 & 631 & 67.7 & 10 & 2.64 & 607.00 & 10.7 & 17.5 & 0.01 & 1.56 & 0.4 & 0.7 \\
\hline Kamchatka-island arc & 37 & 401.74 & 758.87 & 585 & 87.7 & 10 & 0.17 & 22.00 & 63.7 & 66.8 & 0.23 & 7.78 & 2.7 & 2.9 \\
\hline Siberia-craton & 20 & 478.96 & 1652.49 & 831 & 310 & 5 & 0.13 & 45.20 & 82.9 & 187.1 & 0.12 & 11.58 & 2.5 & 5.7 \\
\hline
\end{tabular}


experiments, even in the specimens with high sulfur content [ $\approx 600$ ppm; Alard et al., 2011], shows that the contribution of pyrrhotite to remanence is negligible. Finally, Fe-Ni alloys were not observed during either the electron microscopic study or the rock magnetic measurements.

[15] Pure magnetite is the ferromagnetic mineral most commonly observed in mantle xenoliths. In measurements of room temperature saturation isothermal remanent magnetization (RT-SIRM) on cooling from $300 \mathrm{~K}$ to $10 \mathrm{~K}$, specimens from all four xenolith suites showed $\delta M / \delta T$ maxima at $120-125 \mathrm{~K}$ (Fig. 3A), which corresponds to the Verwey transition of pure magnetite [e.g., Walz, 2002]. This data, along with the electron microscopy results and alternating field demagnetization spectra of NRM (Supporting Information), indicate that magnetite constitutes the dominant NRM carrier. The xenolith's hysteresis properties (Fig. 3B), are consistent with pseudo-single domain (PSD) to single domain (SD) grain sizes for this magnetite.

[16] Two samples from the Siberian craton (U503 and U504) also displayed clear pyrrhotite transitions around $30-34 \mathrm{~K}$ in the low temperature cycling experiments. Thus, although magnetite may be the most frequently observed ferromagnetic mineral in mantle xenoliths, pyrrhotite may also occur on a less frequent basis. However, its
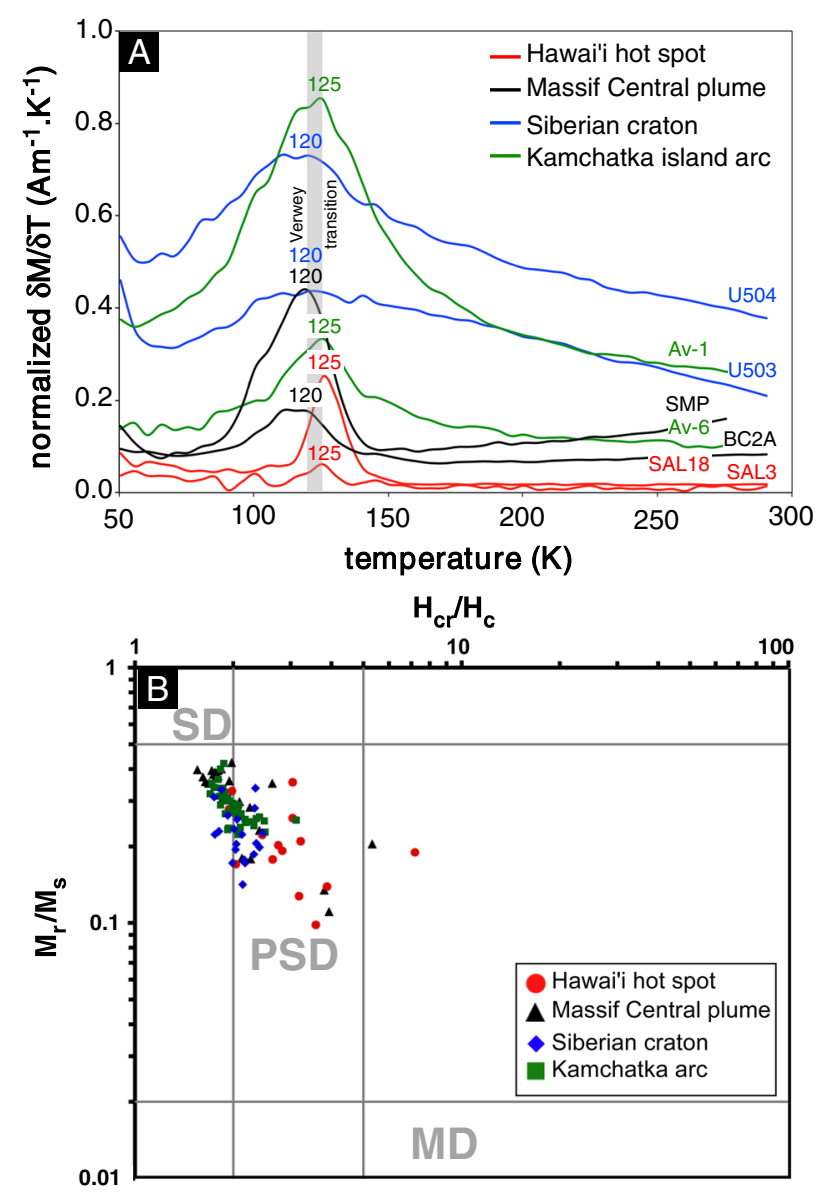

Figure 3. (A) First derivative of magnetization with temperature vs temperature for eight peridotite xenoliths. The 120-125 K Verwey transition shows the presence of magnetite. This data, along with hysteresis properties (Supporting Information), illustrates that PSD to SD magnetite dominates the NRM. (B) Dunlop [2002] plot of all xenolith specimens. comparatively low Curie temperature of $320^{\circ} \mathrm{C}$ makes it unlikely that pyrrhotite contributes to either an induced or remanent magnetization in the lithospheric mantle.

\section{Origin of magnetite in mantle xenoliths}

[17] In mantle peridotites, magnetite is commonly thought to form as a secondary phase through serpentinization at various depths: in the mantle [e.g., Facer et al., 2009], at intermediate depths or near the surface [e.g., Toft et al., 1990]. However, in this study we argue that magnetite can form via diffusive exsolution at mantle depths within both olivine and pyroxene, as well as along primary silicate grain boundaries (Fig. 1). Our strongest evidence for such a claim is magnetite inclusions exsolved in olivine (and frequently associated with orthopyroxene) in xenoliths from Kamchatka. These inclusions are similar to those described by Markl et al. [2001], who proposed a formational mechanism associated with a late stage rise in oxygen fugacity conditions. Indeed, spinel grains in the Kamchatka xenoliths show an increase in $\mathrm{Fe}^{3+}$ from core to rim, consistent with an increase in $\mathrm{fO}_{2}$ due to exposure to late-stage, subduction-related fluids [Ionov, 2010; Goncharov et al., 2012]. These inferences are consistent with data on melt inclusions in spinel from the Kamchatka xenoliths, which trapped low-T melts linked to highly oxidized hydrous fluids expelled from subucted slab [Ionov et al., 2011]. Such oxidizing fluids can be present at mantle depths and may explain the magnetite observed in the other xenolith suites. In the Hawai'i xenoliths, a portion of the magnetite grains are spatially associated with amphibole lamellae, in striking similarity with the inclusions described in gabbroic olivines altered at high temperature by oceanic hydrous fluids [Puga et al., 1999]. Similarly, in the Massif Central xenoliths, the amphibole lamellae exsolved along crystallographic planes in clinopyroxene suggest the availability of $\mathrm{H}_{2} \mathrm{O}$ during exsolution. Our sample selection criteria exclude almost all cases of xenolith serpentinization, however when rare serpentine veins were observed, they do not host magnetite or metal alloys, but only non-ferromagnetic nickel sulfides.

[18] The magnetite exsolution observed in this study is thought to occur during oxidation, at temperatures higher than $600^{\circ} \mathrm{C}$, and has been previously studied in pyroxene [Schlinger and Veblen, 1989] and in olivine [Kohlstedt et al., 1976; Putnis, 1979; Franz and Wirth, 2000; Markl et al., 2001]. In olivine, these exsolved grains tend to display both needle-like and dendritic morphologies and display high coercivities [Brewster and O'Reilly, 1988]. In mantle xenoliths from a seamount, Franz and Wirth [2000] attributed the olivine oxidation event responsible for magnetite exsolution to a $700-800^{\circ} \mathrm{C}$ metasomatic fluid. The exsolved magnetite observed in this study occurs within primary silicates, away from serpentine veins, and is consistent with formation at mantle depths or during the initial stages of ascent.

\section{Potential implications for sub-Moho magnetic sources}

[19] The single component NRM measured in the mantle xenoliths of this study is typical of that acquired through a thermoremanent magnetization process. This NRM was acquired upon cooling of the mantle xenolith at or near the surface of the Earth. These room temperature remanence 
values represent a two to three fold increase with respect to their remanence at depth. In cold geotherm settings, prior to eruption, the mantle source regions were cooler than the melts that transported xenoliths to the Earth's surface. The Curie temperature of pure magnetite increases with pressure/depth [Schult, 1970], such that $\mathrm{T}_{\mathrm{c}}$ is $600^{\circ} \mathrm{C}$ at $1 \mathrm{GPa}$. In cold geotherm settings such as subduction zones (e.g., the Kamchatka arc) and cratons (e.g., Siberia), this pressure dependence may push the Curie depth below the crust-mantle boundary.

[20] Assuming a geotherm of $25^{\circ} \mathrm{C} / \mathrm{km}$, any magnetite present in the mantle would be at temperatures well above its Curie temperature. However, if a geotherm typical of forearc mantle wedges is assumed [e.g., $12^{\circ} \mathrm{C} / \mathrm{km}$, Bostock et al., 2002], then the Curie depth could be as deep as $50 \mathrm{~km}$. Such an arc setting could potentially yield a $10 \mathrm{~km}$-thick layer of 'magnetically cold' uppermost mantle. In this way, the lithospheric mantle may significantly contribute to LWMA, whether it is serpentinized [Blakely et al., 2005] or not [Evans, 2010]. In the most permissive circumstances, with a geotherm of $9^{\circ} \mathrm{C} / \mathrm{km}$ (i.e., surface heat flow of $35-40 \mathrm{~mW} / \mathrm{m}^{2}$ ), such as that of the Siberian craton [Goncharov et al., 2012] and a crust-mantle boundary at $40 \mathrm{~km}$ depth, the layer of potentially magnetized lithospheric mantle could be up to $25 \mathrm{~km}$ thick.

[21] These results demonstrate that the lithospheric mantle displays non-uniform magnetic properties across tectonic settings. The present collections of uppermost mantle rocks are insufficient to produce measurable satellite anomalies but are suggestive of source regions that may significantly contribute to LWMA. Previous work showed that certain lower crustal rocks exhibit high NRM intensities, $>5 \mathrm{Am}^{-1}$, and elevated $Q_{n}$ (from 2 to 7 ), which strongly contribute to some aeromagnetic anomalies [Robinson et al., 2002; McEnroe et al., 2004]. However, in these locations, lacking prominent regional anomalies, NRM intensities appear too modest to contribute to LWMA [Pilkington et al., 2006; Liu et al., 2009; Dunlop et al., 2010].

[22] The measured properties of mantle peridotites would produce magnetization contrasts around 0.02 to $0.03 \mathrm{~A} / \mathrm{m}$, resulting in peak-to-trough anomalies of 0.08 to $0.10 \mathrm{nT}$ at $300 \mathrm{~km}$ altitude for a $10-\mathrm{km}$ thick slab of magnetized mantle. Although these anomalies remain below the noise level of current magnetic satellites, such features will likely become detectable by the future SWARM satellites.

[23] Although the magnetization of uppermost mantle rocks may appear relatively weak it may provide a supplemental source in areas where crustal magnetizations are too low to explain the observed anomalies. Assuming that all LWMA originate from crustal sources requires crustal sources that are in many cases more strongly magnetizated than observations suggest. A magnetized uppermost mantle may provide the missing magnetization. The demonstration of ferromagnetic material in the lithospheric mantle necessitates a re-evaluation of the long held non-magnetic mantle model, and could potentially affect the interpretation of previous and future satellite-derived magnetic data including that from the SWARM mission. In short, deep crustal rocks need not be as strongly magnetized if the upper mantle contributes to long wavelength magnetic anomalies.

[24] Acknowledgments. We thank A. Tommasi and O. Alard for providing Hawai'i and Massif Central samples. D. Ionov acknowledges N.P. Pokhilenko, A. Golovin and I. Ashchepkov (V.S. Sobolev Institute of Geology and Mineralogy, Novosibirsk) and ALROSA for access to Udachnaya and collections, and CNRS PNP and PICS grants in 2010-2012. S.A.F. thanks the Geological Society of America and the Institute for Rock Magnetism for support. Reviewers David Clark and David Dunlop provided insightful reviews that helped clarifying key aspects of this research.

\section{References}

Alard, O., J.-P. Lorand, L. Reisberg, J. L. Bodinier, J. M. Dautria, and S. Y. O'Reilly (2011), Volatile-rich metasomatism in Montferrier xenoliths (Southern France): Implications for the abundances of chalcophile and highly siderophile elements in the subcontinental mantle, J. Petrol., 52, 2009-2045.

Arkani-Hamed, J., and D. W. Strangway (1987), An interpretation of magnetic signatures of subduction zones detected by MAGSAT, Tectonophysics, 133(1-2), 45-55.

Blakely, R. J., T. M. Brocher, and R. E. Wells (2005), Subduction-zone magnetic anomalies and implications for hydrated forearc mantle, Geology, 33, 445-448.

Bostock, M. G., R. D. Hyndman, S. Rondenay, and S. M. Peacock (2002), An inverted continental Moho and serpentinization of the forearc mantle, Nature, 417, 536-538.

Brewster, D., and W. O'Reilly (1988), Magnetic properties of synthetic analogues of the altered olivines of igneous rocks, Geophys. J., 95, 421-432.

Chiozzi, P., J. Matsushima, Y. Okubo, V. Pasquale, and M. Verdoya (2005), Curie-point depth from spectral analysis of magnetic data in central-southern Europe, Phys. Earth Planet. Inter., 152, 267-276.

Counil, J.-L., J. Achache, and A. Galdeano (1989), Long-wavelength magnetic anomalies in the Caribbean: Plate boundaries and allochthonous continental blocks, J. Geophys. Res: Solid Earth, 94(B6), 7419-7431.

Demouchy, S., S. D. Jacobsen, F. Gaillard, and C. R. Stern (2006), Rapid magma ascent recorded by water diffusion profiles in mantle olivine, Geology, 34, 429-432.

Drury, M. R., and H. L. M. van Roermund (1988), Metasomatic origin for Fe-Ti-rich multiphase inclusions in olivine from kimberlite xenoliths, Geology, 16, 1035-1038.

Dunlop, D. J. (2002), Theory and application of the Day plot $\left(\mathrm{M}_{\mathrm{rs}} / \mathrm{M}_{\mathrm{s}}\right.$ versus $\left.\mathrm{H}_{\mathrm{cr}} / \mathrm{H}_{\mathrm{c}}\right)$. 1. Theoretical curves and tests using titanomagnetite data, J. Geophys. Res.: Solid Earth, 107(B3), 2056, doi:2010.1029/ 2001JB000486.

Dunlop, D. J., Ö. Özdemir, and V. Costanzo-Alvarez (2010), Magnetic properties of rocks of the Kapuskasing uplift (Ontario, Canada) and origin of long-wavelength magnetic anomalies, Geophys. J. Int., 183, $645-658$.

Evans, B. W. (2010), Lizardite versus antigorite serpentinite: Magnetite, hydrogen, and life(?), Geology, 38, 879-882.

Facer, J., H. Downes, and A. Beard (2009), In situ serpentinization and hydrous fluid metasomatism in spinel dunite xenoliths from the Bearpaw Mountains, Montana, USA, J. Petrol., 50, 1443-1475.

Franz, L., and R. Wirth (2000), Spinel inclusions in olivine of peridotite xenoliths from TUBAF seamount (Bismarck Archipelago/Papua New Guinea): evidence for the thermal and tectonic evolution of the oceanic lithosphere, Contrib. Mineral. Petrol., 140, 283-295.

Friis-Christensen, E., H. Lühr, and G. Hulot (2006), Swarm: A constellation to study the Earth's magnetic field, Earth Planets Space, 58, 351-358.

Frost, D. J., and C. A. McCammon (2008), The redox state of Earth's mantle, Ann. Rev. Earth Planet. Sci., 36, 389-420.

Goncharov A. G., D. A. Ionov, L. S. Doucet, L. N. Pokhilenko (2012), Thermal state, oxygen fugacity and $\mathrm{C}-\mathrm{O}-\mathrm{H}$ fluid speciation in cratonic lithospheric mantle: new data on peridotite xenoliths from the Udachnaya kimberlite, Siberia, Earth Planet. Sci. Lett., 357-358, 99-110: doi: 10.1016/j.epsl.2012.09.016

Ionov, D. A. (2010), Petrology of mantle wedge lithosphere: New data on supra-subduction zone peridotite xenoliths from the andesitic Avacha volcano, Kamchatka, J. Petrol., 51, 327-361.

Ionov, D. A., L. S. Doucet, and I. V. Ashchepkov (2010), composition of the lithospheric mantle in the Siberian craton: New constraints from fresh peridotites in the Udachnaya-East kimberlite, J. Petrol., 51, 2177-2210.

Ionov D. A., A. Bénard, P. Plechov (2011), Melt evolution in subarc mantle: evidence from heating experiments on spinel-hosted melt inclusions in peridotite xenoliths from the andesitic Avacha volcano (Kamchatka, Russia). Contrib. Mineral. Petrol., 162, 1159-1174.

Kohlstedt, D. L., C. Goetze, W. B. Durham, and J. V. Sande (1976), New technique for decorating dislocations in olivine, Science, 191, 1045-1046.

Lenoir, X., C. J. Garrido, J.-L. Bodinier, and J.-M. Dautria (2000), Contrasting lithospheric mantle domains beneath the Massif Central (France) 


\section{FERRE ET AL.: MAGNETISM OF THE MANTLE}

revealed by geochemistry of peridotite xenoliths, Earth Planet. Sci. Lett., 181, 359-375.

Liu, Q., Q. Liu, T. Yang, Q. Zeng, J. Zheng, Y. Luo, N. Qiu, H. Xu, and Z. Jin (2009), Magnetic study of the UHP eclogites from the Chinese Continental Scientific Drilling (CCSD) Project, J. Geophys. Res.: Solid Earth, 114, B02106.

Markl, G., M. Marks, and R. Wirth (2001), The influence of $T, a_{\mathrm{SiO} 2}$, and $f \mathrm{O}_{2}$ on exsolution textures in Fe-Mg olivine: An example from augite syenites of the Ilimaussaq Intrusion, South Greenland, Am. Mineral., 86, 36-46.

Maus, S., H. Lühr, M. Rother, K. Hemant, G. Balasis, P. Ritter, and C. Stolle (2007), Fifth-generation lithospheric magnetic field model from CHAMP satellite measurements, Geochem. Geophys. Geosyst., 8, Q05013.

McEnroe, S. A., F. Langenhorst, P. Robinson, G. D. Bromiley, and C. S. J. Shaw (2004), What is magnetic in the lower crust? Earth Planet. Sci. Lett., 226, 175-192.

Peslier, A. H., A. B. Woodland, and J. A. Wolff (2008), Fast kimberlite ascent rates estimated from hydrogen diffusion profiles in xenolithic mantle olivines from southern Africa, Geochim. Cosmochim. Acta, 72, 2711-2722.

Pilkington, M., D. B. Snyder, and K. Hemant (2006), Weakly magnetic crust in the Canadian Cordillera, Earth Planet. Sci. Lett., 248, 476-485.

Puga, E., M. D. R. Cruz, and A. D. De Frederico (1999), Magnetite-silicate inclusions in olivine of ophiolitic metagabbros from the Mulhacén Complex, Betic Cordillera, Southeastern Spain, Can. Mineral., 37, 1191-1209.

Putnis, A. (1979), Electron petrography of high-temperature oxidation in olivine from the Rhum layered intrusion, Min. Mag., 43, 293-296.
Robinson, P., R. J. Harrison, S. A. McEnroe, and R. B. Hargraves (2002), Lamellar magnetism in the haematite-ilmenite series as an explanation for strong remanent magnetization, Nature, 418(6897), 517-520.

Schlinger, C. M., and D. R. Veblen (1989), Magnetism and transmission electron microscopy of $\mathrm{Fe}-\mathrm{Ti}$ oxides and pyroxenes in a granulite from Lofoten, Norway, J. Geophys. Res.: Solid Earth, 94, 14009-14026.

Schmidbauer, E. (1983), Magnetization of Fe-Cr-Ti spinels, Phys. Chem. Min., 9, 124-126.

Schult, A. (1970), Effect of pressure on the Curie temperature of titanomagnetites $\left[(1-\mathrm{x}) \cdot \mathrm{Fe}_{3} \mathrm{O}_{4}-\mathrm{x} . \mathrm{TiFe}_{2} \mathrm{O}_{4}\right]$, Earth Planet. Sci. Lett., 10, 81-86.

Sen, G. (1988), Petrogenesis of spinel lherzolite and pyroxenite suite xenoliths from the Koolau shield, Oahu, Hawaii: Implications for petrology of the post-eruptive lithosphere beneath Oahu, Contrib. Mineral. Petrol., 100, 61-91.

Sen, G., and R. E. Jones (1988), Exsolved silicate and oxide phases from clinopyroxenes in a single Hawaiian xenolith: Implications for oxidation state of the Hawaiian upper mantle, Geology, 16, 69-72.

Toft, P. B., J. Arkani-Hamed, and S. E. Haggerty (1990), The effects of serpentinization on density and magnetic susceptibility; a petrophysical model, Phys. Earth Planet. Inter., 65, 137-157.

Walz, F. (2002), The Verwey transition - a topical review, J. Phys. Condensed Matter, 14, 285-340.

Wasilewski, P. J., and M. A. Mayhew (1992), The Moho as a magnetic boundary revisited, Geophys. Res. Lett., 19, 2259-2262.

Wasilewski, P. J., H. H. Thomas, and M. A. Mayhew (1979), The Moho as a magnetic boundary, Geophys. Res. Lett., 6, 541-544. 